\title{
Outpatient physiotherapy services in Latvian regional hospitals: Characteristics of receivers, the volume of services and source of funding
}

\author{
Ilze Heize ${ }^{1}$ and Daina Smite $^{2}$ \\ ${ }^{1}$ Rīga Stradinsš University, Latvia \\ ${ }^{2}$ Rīga Stradiņš University, Department of Rehabilitation, Latvia
}

\begin{abstract}
Objective: To analyse the outpatient physiotherapy services provided in the regional hospitals of Latvia in 2017 and the profile of their receivers. Methods: In the research, 7 regional hospitals of Latvia participated, in which the analysis of statistical documentation of 2017 was carried out. The following data was collected about the receivers of outpatient physiotherapy services: age, gender, clinical diagnosis and place of residence; about the volume of service provided - the number of visits per patient; about the source of funding (state budget, private resources, insurance). Results: In the regional hospitals of Latvia, outpatient physiotherapy services in 2017 were received by 6957 patients, the most commonly adults of working age with basic clinical diagnosis of the musculoskeletal system and connective tissue diseases, and children up to the age of one year with diagnosis of certain conditions originating in the perinatal period. Among the regional hospitals of Latvia there are significant differences in the volume of outpatient physiotherapy services provided to one patient with a similar clinical diagnosis and age. Latvian regional hospitals still do not have electronic records of all outpatient physiotherapy services, which does not allow to judge about provided services and their receivers, which are financed by patients private resources.
\end{abstract}

Key words: outpatient physiotherapy services, physical therapists, regional hospitals.

\section{Introduction}

Outpatient care - health services provided to patients who are not confined to an institutional bed as inpatients during the time the services are rendered [1].

Physical therapists practise in a wide variety of settings that may include, but are not confined to, the following: hospitals, nursing homes, physical therapists' private offices, practices, clinics, rehabilitation centres, outpatient clinics [2]. It has been found that outpatient physiotherapy services have proven their effectiveness (both clinical and cost-effectiveness) when comparing different forms of physiotherapy services [3, 4]. Understanding the patient's profile is important not only for decision-making in the therapeutic process [5], but also for adjusting healthcare services to patient's changing needs [6].

Physiotherapists in Latvia provide their services in different environments providing outpatient, inpatient and home care physiotherapy services (services are provided both from the state budget and the private funds of the patient, including private insurance funds). Outpatient physiotherapy services in Latvia are in great demand, with different waiting time 
Table 1. Data selection.

\begin{tabular}{|l|c|c|c|c|}
\hline Hospital & $\begin{array}{c}\text { Outpatient } \\
\text { Physiotherapy } \\
\text { patients }(\boldsymbol{n})\end{array}$ & $\begin{array}{c}\text { The volume } \\
\text { of service } \\
\text { provided }\end{array}$ & $\begin{array}{c}\text { Excluded } \\
\text { patients } \\
(\boldsymbol{n})\end{array}$ & $\begin{array}{c}\text { Included } \\
\text { patients } \\
(\boldsymbol{n})\end{array}$ \\
\hline Liepāja regional hospital & 1672 & 8573 & 2 & 1670 \\
\hline Jēkabpils regional hospital & 2540 & 7726 & 0 & 2540 \\
\hline Vidzeme hospital & 1851 & 17000 & 177 & 1674 \\
\hline Daugavpils regional hospital & 1161 & $11286($ state $)$ & 418 & 743 \\
\hline Jelgava city hospital & 71 & 171 (charged) & 0 & 71 \\
\hline North Kurzeme regional hospital & 744 & 3842 & 485 & 259 \\
\hline Rēzekne hospital & 3673 & unknown & 3673 & 0 \\
\hline
\end{tabular}

for access in different institutions, but compared to the waiting time of other functional specialist services - it is the longest [7].

In Latvia, there are no statistics available about the provided outpatient physiotherapy services or about the receivers' characteristics. That would allow purposeful organizational activities for most commonly provided mono-professional outpatient rehabilitation service.

The objective of the research was to analyse the outpatient physiotherapy services provided in the regional hospitals of Latvia in 2017 and the profile of their receivers.

The tasks of the research were to collect and analyze the data on the characteristics of the receivers, the volume of services and source of funding of outpatient physiotherapy services provided by regional hospitals of Latvia in 2017.

\section{Methods}

\subsection{Data sources and procedure}

In the research, 7 (all) regional hospitals of Latvia participated, in which the analysis of statistical documentation of 2017 was carried out.

The study was carried out between 22.01.2018 - 31.03.2018. The design was quantitative, non-experimental, retrospective research. The approval for this study was obtained from the Ethics Committee of Rīga Stradinš̌ University and from the chairmen of the board of hospitals involved in the study. After obtaining permissions to obtain the necessary data, requests for the necessary information were sent electronically to the medical statistics units of the involved hospitals.

Data were collected about: the receivers of outpatient physiotherapy services (age, gender, clinical diagnosis and place of residence), the volume of service provided (the number of visits per patient); the source of funding (state budget, private resources, insurance). Descriptive data were analysed in general, by hospitals, as well as volume of service depending on the patient's clinical diagnosis, age, place of residence was analyzed in the total sample and in each hospital.

The study included only valid or usable (containing full information) data in electronic form, incomplete data were excluded (data selection is shown in Table 1). Due to various factors, in "Daugavpils regional hospital", "Vidzeme hospital" and in "North Kurzeme regional hospital" valid data were only available about the receivers and received services provided by state budget. "Rezekne hospital" does not perform electronic accounting of outpatient services provided, so data were excluded. Two patients from "Liepaja regional hospital" were excluded from the data analysis due to the large volume of services (number of visits per patient $>100$ ). 


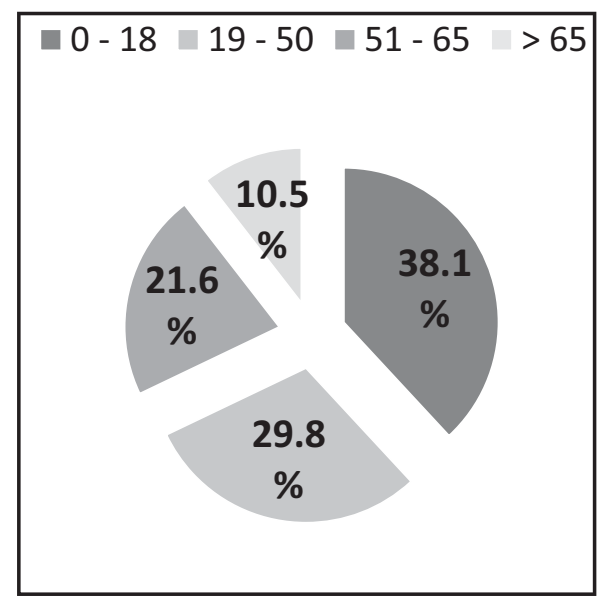

Fig. 1. Distribution of patients (\%) by age (years).

\subsection{Statistical analysis}

The results were analyzed using Microsoft Excel, IBM SPSS Statistics 24.0 and StatPlus v.s.6.2.30 software. In statistical analysis descriptive statistics and analytical statistics were used. The statistically significant level was $p<0.05$.

\section{Results}

\subsection{Characteristics of receivers}

\subsubsection{Age and gender}

In regional hospitals of Latvia in 2017, 6957 patients received outpatient physiotherapy services, of which $39.1 \%(n=2721)$ were men and $60.9 \%(n=4236)$ were women.

The mean age of patients was $33.5 \pm 24.8$ years (minimal age -0 , maximal age -98 ), median was 35 years (25\% percentile - 10 years, $75 \%$ percentile -55 years). From the total number of patients $38.1 \%(n=2650)$ were aged under 18 (children). From the total number of patients who had received physiotherapy services $51.4 \%(n=3574)$ were at working age (19-65 years). Distribution of patients by age is illustrated in Fig. 1.

Differences were found between age, considering the gender $(p<0.001)-$ for women the median was 43 years (25\% percentile -14 years, $75 \%$ percentile -58 years) and for men 20 years $(25 \%$ percentile -5 years, $75 \%$ percentile -72.8 years $)$.

\subsubsection{Clinical diagnosis}

Outpatient physiotherapy services provided by regional hospitals were received by patients whose primary clinical diagnosis corresponded to one of the 17 diagnostic code groups (by ICD-10).

From the total number of analyzed patients, 54.2\% $(n=3769)$ were diagnosed with diseases of the musculoskeletal system and connective tissue (M00-M99), 12\% were diagnosed with certain conditions originating in the perinatal period (P00-P96). Detailed distribution by diagnosis is shown in Fig. 2. 


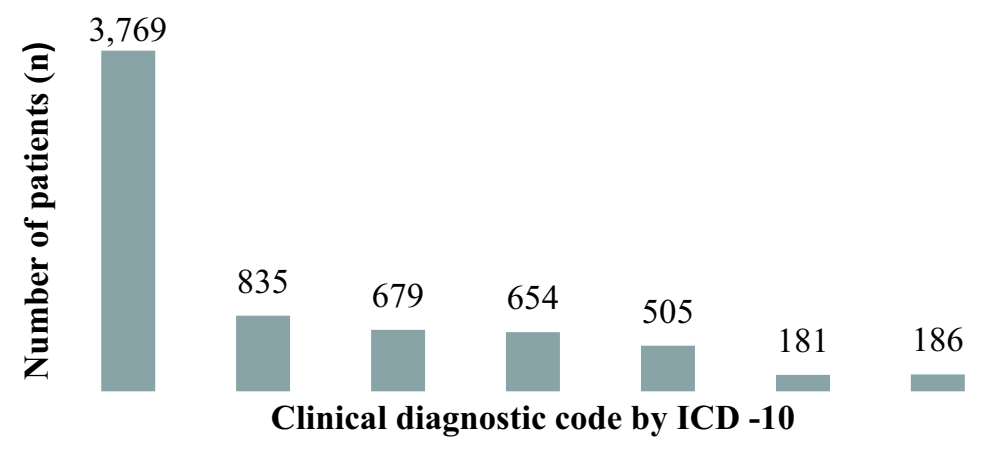

Fig. 2. Distribution of patients by diagnosis.

\subsubsection{Place of residence}

From the total number, $62.2 \%$ of patients lived in the town of hospital localization and only $37.8 \%$ lived in the region. Only The Vidzeme hospital has a higher proportion of patients with place of residence in regions $-59.9 \%$ of Vidzeme hospital patients. There were no gender or age differences by place of residence.

\subsection{The volume of services and connection with the characteristics of the receivers}

The total number of outpatient physiotherapy services, provided in regional hospitals in 2017 , was 37312 visits. Number of visits per patient varies from 1 to 91 . The median volume of service per patient per year was 5 visits ( $25 \%$ percentile -2 visits, $75 \%$ percentile -10 visits).

It was found that patients with place of residence in hospital localization city received more services than those patients with place of residence in region.

Analyzing the data, it was found that the visits per patient were reliably related to the patients' diagnosis. Fewer visits per patient (median 2 and 3 visits per patient) had patients with diagnosis from P00-P96 and R00-R99 diagnostic codes compared to patients with diagnosis from M00-M99, S00-T98 and I00-I99 diagnostic codes (median - 5 visits per patient).

Statistically significant differences were found when analyzing the number of visits per patient in different hospitals $(p<0.001)$ : the highest number of visits per patient was at Daugavpils regional hospital (median - 10 visits per patient), but the lowest number of visits per patient was at Jekabpils regional hospital (median -3 visits per patient). At Liepaja regional hospital median number of visits per patient was 5 visits per patient, at North Kurzeme regional hospital median was 7 visits per patient.

The distribution of number of visits per patients by diagnosis (and by age groups in each hospital) is shown in Table 2, Table 3, Table 4 and in Table 5. Among the regional hospitals of Latvia there are significant differences in the volume of outpatient physiotherapy services, provided to one patient with a similar clinical diagnosis and age.

\subsection{Source of funding}

It was not possible to analyze data on the source of funding because of the lack of available, complete data on services provided by the patient's private or insurer's funds. 
Table 2. The number of visits per child's age patient in different hospitals.

\begin{tabular}{|l|c|c|c|}
\hline Hospital & \multicolumn{3}{|c|}{ Age } \\
\hline & $\mathbf{0 - 1}$ & $\mathbf{2 - 6}$ & $\mathbf{7 - 1 8}$ \\
\hline Liepaja regional hospital & 6.0 & 7.2 & 6.3 \\
\hline Jekabpils regional hospital & 1.9 & 3.0 & 3.2 \\
\hline Vidzeme hospital & 6.4 & 8.4 & 10.2 \\
\hline Daugavpils regional hospital & 19.7 & 19.4 & 23.6 \\
\hline North Kurzeme regional hospital & 4.2 & 8.6 & 9.8 \\
\hline
\end{tabular}

Table 3. The number of visits per patient in different hospitals. Patients with group M00-M99 diagnosis (by ICD-10).

\begin{tabular}{|l|c|c|c|}
\hline Hospital & \multicolumn{3}{|c|}{ Age } \\
\hline & $\mathbf{1 9 - 5 0}$ & $\mathbf{5 1 - 6 5}$ & $>\mathbf{6 5}$ \\
\hline Liepaja regional hospital & 5.4 & 4.7 & 5 \\
\hline Jekabpils regional hospital & 3.2 & 3.3 & 3.4 \\
\hline Vidzeme hospital & 9.5 & 10.8 & 9.8 \\
\hline Daugavpils regional hospital & 12 & 14 & 14.7 \\
\hline North Kurzeme regional hospital & 10.7 & 12.4 & 12.4 \\
\hline
\end{tabular}

Table 4. The number of visits per patient in different hospitals. Patients with group S00-T98 diagnosis (by ICD - 10).

\begin{tabular}{|l|c|c|c|}
\hline Hospital & \multicolumn{3}{|c|}{ Age } \\
\hline & $\mathbf{1 9 - 5 0}$ & $\mathbf{5 1 - 6 5}$ & $>\mathbf{6 5}$ \\
\hline Liepaja regional hospital & 6.9 & 7.6 & 8.8 \\
\hline Jekabpils regional hospital & 3.3 & 4.3 & 3.8 \\
\hline Vidzeme hospital & 11.7 & 11.6 & 17.4 \\
\hline Daugavpils regional hospital & 12.3 & 11.0 & 13.1 \\
\hline North Kurzeme regional hospital & 16.8 & 14 & 4 \\
\hline
\end{tabular}

Table 5. The number of visits per patient in different hospitals. Patients with group I00-I99 diagnosis (by ICD - 10).

\begin{tabular}{|l|c|c|c|}
\hline Hospital & \multicolumn{3}{|c|}{ Age } \\
\hline & $\mathbf{1 9 - 5 0}$ & $\mathbf{5 1 - 6 5}$ & $\mathbf{> 6 5}$ \\
\hline Liepaja regional hospital & $8 / 10 / 20$ & 5.8 & 3.5 \\
\hline Jekabpils regional hospital & 3.6 & 5.3 & 4.3 \\
\hline Vidzeme hospital & $6 / 16$ & 7.1 & 7.7 \\
\hline Daugavpils regional hospital & 14.5 & 20.3 & 15.1 \\
\hline North Kurzeme regional hospital & - & 14 & $7 / 6$ \\
\hline
\end{tabular}

\section{Discussion}

The study revealed that there is a significant difference between the number of patients who had received outpatient physiotherapy services in different Latvian regional hospitals - the highest number of patients $(n=2540)$ was found at Jekabpils regional 
hospital, while the lowest at North Kurzeme regional hospital - only 259 patients. Perhaps the significant difference is affected by the activity of other service providers in the region (other healthcare facilities located in the regional hospital localization cities, as well as healthcare facilities in the regions that have a contract with the National Health Service and also provide outpatient physiotherapy services using state budget funds. According to National Health Service data, at least one outpatient health care centre is located in Valmiera, Daugavpils, Liepaja, Ventspils and Talsi which also provides outpatient physiotherapy services, while in Jèkabpils there is only one private practice which provides outpatient physiotherapy services by the state budget funds [8].

It was found that the $38.1 \%$ of outpatient physiotherapy receivers were children (most often infants) and $51.4 \%$ were adults at working age, but only $10.5 \%$ of receivers were over 65 years old. Attention should be paid to the low proportion of seniors. Literature shows that old-age individuals are often diagnosed with at least one or more chronic illnesses [9] and the aging process is characterized by the increase of functional limitations [10], which justifies the need of rehabilitation services.

It should be emphasized that only $2.6 \%(n=178)$ of all patients who received outpatient physiotherapy had a primary clinical diagnostic code from I00-I99 (diseases of the circulatory system), including after stroke (I69.1, I69.3, I63). According to the data of the Central Statistical Bureau of Latvia, in 2016, disability was granted for the first time to 3906 persons suffering from diseases of the circulatory system, including stroke [11]. It is known that stroke has long-lasting consequences, most often having a negative impact on several body functions such as mobility, coordination and the ability to perform daily activities [12, 13]. For this reason, it is particularly important to provide qualitative rehabilitation services for these persons, it has been proven that outpatient, hospital-based stroke rehabilitation is effective in improving the physical functioning of stroke patients [14].

Among the regional hospitals of Latvia there are significant differences in the volume of outpatient physiotherapy services, provided to one patient with a similar clinical diagnosis and age. Unfortunately, the clinical diagnosis does not allow us to judge the severity of functional limitations, but there is no reason for argument that there are significant differences in functional limitations for patients from different regions. Such differences indicate that there are no established guidelines to define the algorithm how and how much to work with certain types of patients depending on their functional status and the purpose of the outpatient physiotherapy service.

\section{Conclusions}

The profile of receivers of outpatient physiotherapy services, provided by regional hospitals in Latvia, is characterized by adults of working age with basic clinical diagnosis of musculoskeletal system and connective tissue diseases (most commonly spondylosis and intervertebral disc disorders) and by children under the age of one, with diagnosis of certain conditions originating in the perinatal period (most commonly disorders of muscle tone of a newborn). It can be concluded that outside of the range of service receivers stay seniors, since the age structure of population, the increase of chronic diseases and functional limitations with aging, justify the need of rehabilitation services.

Among the regional hospitals of Latvia there are significant differences in the volume of outpatient physiotherapy services, provided to one patient with a similar clinical diagnosis and age. Given that there is no reason for argument that there are significantly different functional limitations for patients from different regions, it can be concluded that there is a difference in the content and planning of the service, and in cooperation model between specialists. 
Latvian regional hospitals still do not have electronic records of all outpatient physiotherapy services, which does not allow judging about provided services and their receivers, which are financed by patients' private resources.

\section{References}

[1] World Health Organization, Assessing health services delivery performance with hospitalizations for ambulatory care sensitive conditions (2016)

[2] World Confederation for Physical Therapy (2017). Available at: https://www . wcpt.org/policy/ps-descriptionPT

[3] J.D. Childs, J.S. Harman, J.R. Rodeghero, M. Horn, S.Z. George, J. Orthop Sports Phys. Ther. 44, 955 (2014)

[4] J. Zeidler, T. Mittendorf, G. Vahldiek, H. Zeidler, S. Merkesdal, Rheum. 47, 1527 (2008)

[5] K. Lutfey, S.M. Campbell, M.R. Renfrew, L.D. Marceau, M. Roland, J.B. McKinlay, Soc. Sci. Med. 67, 1391 (2008)

[6] Ensocare, How Demographics Impact Healthcare Delivery (2017), Available at: https://www . ensocare.com/resource-center/how-demographics-impacthealth-care-delivery

[7] The National Health Service (2017), Available at: http://www.vmnvd.gov.lv/lv/ veselibas-aprupes-pakalpojumi/ambulatoro-pakalpojumu-gaidisanasrindas

[8] The National Health Service (2018), Available at: http: //www . vmnvd.gov. Iv/lv/ 503-ligumpartneriem/507-ligumiestazu-saraksts

[9] B.W. Ward, J.S. Schiller, R.A. Goodman, Prev. Chronic Dis. 11, 1 (2014)

[10] J.H. Billson, I. Shaw, B.S. Shaw, African J. Phys. Health Edu. Recreat. Dance 18, 672 (2012)

[11] Central Statistical Bureau of Latvia, VAG13 (2017), Available at: http://data. csb.gov.1v/pxweb/lv/Sociala/Sociala__ikgad__veseliba/VA0130.px/ table/tableViewLayout2/?rxid=cdcb978c-22b0-416a-aacc-aa650d3e2ce0

[12] R. Luengo-Fernandez, N.L.M. Paul, A.M. Gray, S.T. Pendlebury, L.M. Bull, S.J.V. Welch, F.C. Cuthbertson, P.M. Rothwell, Stroke 44, 2854 (2013)

[13] M. Mollaoglu, T.K. Fertelli, F.O. Tuncay, Arch. Gerontol. Geriatr. 53, e227 (2011)

[14] D. Rice, S. Janzen, A. McIntyre, J. Vermeer, E. Britt, R. Teasell, J. Stroke Cerebrovasc. Dis. 25, 1158 (2016) 